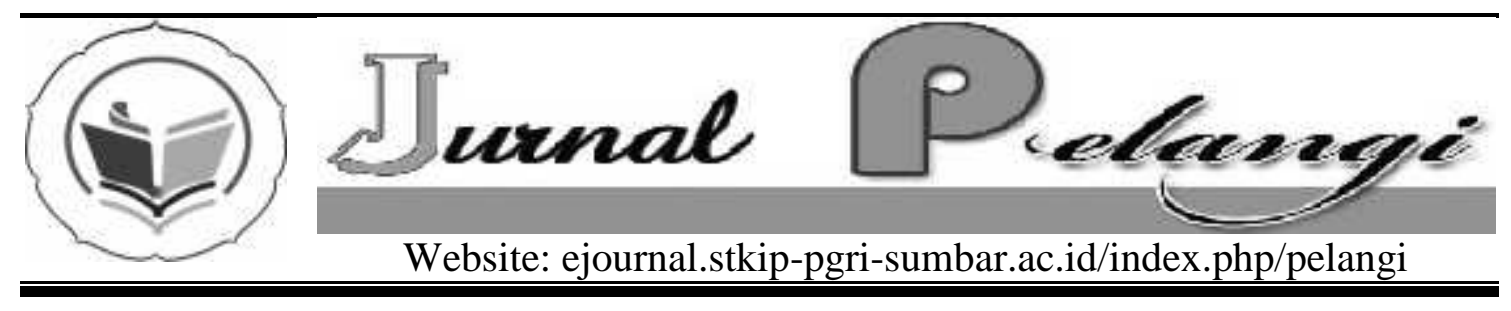

\title{
IMPROVING STUDENTS' READING COMPREHENSION THROUGH SUMMARIZING STRATEGY AT JUNIOR HIGH SCHOOL
}

\author{
Herfyna Asty \\ STKIP PGRI Sumatera Barat \\ herfynaasti@yahoo.com
}

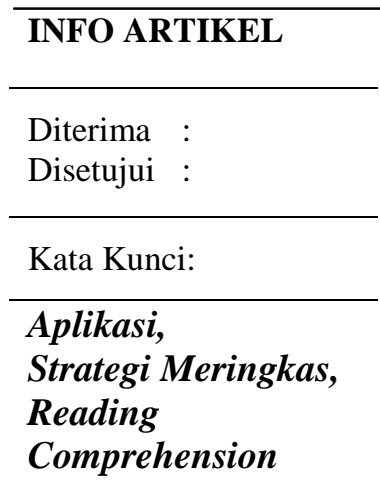

\begin{abstract}
Abstrak
Hasil obseervasi menunjukkan bahwa ada lima masalah yang dihadapi oleh siswa dalam mata kuliah Reading Comprehension : pertama, siswa malas untuk membaca teks bahasa Inggris; kedua, siswa menemukan kesulitan untuk memahami isi teks bacaan karena mereka memiliki keterbatasan kosakata; ketiga, siswa tidak memiliki cukup waktu karena mereka telah sibuk untuk berkonsultasi dengan kamus untuk mencari kata-kata sulit yang mereka temukan pada teks bacaan; keempat, para siswa sangat pasif selama proses belajar mengajar di kelas; dan kelima, teknik mengajar yang digunakan oleh guru tidak menarik untuk para siswa.

Untuk mengatasi masalah tersebut, penelitian tindakan kelas dilakukan dengan menerapkan strategi meringkas dilakukan. Hasil penelitian menunjukkan bahwa penerapan strategi meringkas pada kelas Reading Comprehension berhasil meningkatkan kemampuan siswa pada tes Reading Comprehension. Keberhasilan ini dibuktikan oleh oleh peningkatan nilai rata-rata siswa dari siklus 1 ke siklus 2. Nilai rata-rata selama siklus 1 adalah 64,13, dan nilai ratarata selama siklus 2 adalah 69,88, dan selama siklus 3 adalah 72,38. Selanjutnya, persepsi siswa tentang penerapan strategi meringkas untuk kelas membaca kelas juga membaik. Hal ini didukung oleh persentase rata-rata persepsi positif 40,5 pada siklus 1, 73,9, pada siklus. 2, 84,6 pada siklus 3. Dengan demikian, dapat disimpulkan bahwa strategi meringkas efektif untuk meningkatkan pemahaman membaca siswa. Selain itu, strategi ini juga meningkatkan persepsi siswa tentang penerapan strategi untuk kelas membaca
\end{abstract}




Abstract
The observations showed that there were five problems faced
by the students in reading comprehension class : (1) students
were lazy to read English texts; (2) students fount difficulty to
understand the contents of reading text because the have
limited vocabulary; (3) students did not have enough time
because they have busy to consult the dictionary for any
difficult words they found on the reading text; (4) the students
were extremely passive during the class; and (5) the teaching
technique used by the teacher was not interesting to the
students.
To solve the problems, a classroom action research of applying
the summarizing strategy was conducted. The results showed
that the application of the summarizing strategy to reading
comprehension classes successfully improve students'
performance on reading comprehension tests. This success was
confirmed by increasing average students score during cycle 1
to cycle 2 . The average score during cycle 1 was 64.13 , the
average score during cycle 2 was 69.88 , and that during cycle 3
was 72.38 . Furthermore, students perceptions of the
application of summarizing strategy to reading classes were
also improving. These were supported by average percentages
of positive perception of 40.5 in cycle 1 , 73.9 in cycle $2,84.6$
in cycle 3 .
Thus, it was concluded that the summarizing strategy id
effective to improve students' reading comprehension. In
addition, the strategy also enhances students' perceptions of
the application of the strategy to reading classes.

\section{INTRODUCTION}

Generally speaking, reading may be defined as a process in which the reader attempts to grasp the messages provided for by the writer in a reading text. In other words, comprehending the messages is the primary purpose of reading. A good reader easily identifies which parts are important and which ones are not. On the other hand, a bad reader cannot recognize the differences between key ideas and complementary ideas. Therefore, reading comprehension is not a problem to some students, but it is a real problem to some others.

The students are asked to focus their attention on important parts of a reading text rather than spending their precious time on finding out the meaning of each unfamiliar word by consulting their dictionaries. The important parts include the topic, the main idea, and the supporting details of each paragraph. If they can catch these important parts, then they will comprehend the text.

With respect to the writer's observations at junior high school, most students did not have adequate reading comprehension ability. When the teacher asked them to read a text and then answer the following questions, most of them could not answer the questions correctly. There are several potential causes of the condition: the learner himself, the teaching material, and the teaching strategy. The 
learner himself plays very influential roles, too. No matter how brilliant the teacher is in teaching reading, the student will not be able to absorb his explanation if he is lacking in motivation to learn. In fact, reading involves several prerequisites skills in: identifying the organization of the ideas, recognizing the grammatical forms and syntactic patterns, understanding the structures and lexical items of the reading passage, and understanding the graphic conventions of reading such as punctuation and spelling. Their low motivation to learn English seriously will make them have unsatisfactory skills in the five components of reading. Of course, their mastery of the five skills highly determines their ability to comprehend a reading passage. This poor motivation is further complicated by students' bad reading habit. The students tend to try to understand the meaning of each unfamiliar word during their reading activity. As a result, they spend most of their time on consulting their dictionaries so that they cannot answer the following questions correctly because they miss the important parts of the reading text. Only a few of them can complete reading comprehension exercise well.

The summarizing strategy can facilitate students to comprehend a reading text effectively by leading them to focus their attention on the important parts and skip the less important ones. Hence, to help English teacher solve the aforementioned problems, the writer will try to apply this strategy to the teaching of reading comprehension at junior high school. To solve the three problems, the researcher focuses her attention on improving students reading comprehension through the summarizing strategy. The strategy will be applied to the second year students of junior high school. The research is aimed at finding out the effectiveness of the summarizing strategy in improving students' reading comprehension. It is expected that the research will result in invaluable benefits to English teachers, educators, and students. To the English teachers, this research will solve the problems with which they are faced in reading class. In turn, the research will help them improve their students' reading comprehension.

\section{Review of the Related Theories Reading Comprehension}

Song (1998) states that a vast amount of research in first language reading and reading strategies has found that good readers are better at monitoring their comprehension than poor readers, that they are more aware of the strategies they use than are poor readers, and that they use strategies more flexibly and efficiently. For example, good readers distinguish between important information and details as they read and are able to use clues in the text to anticipate information and/or relate new information to information already stated. They are also able to notice inconsistencies in a text and employ strategies to make these inconsistencies understandable.

\section{Summarizing Strategy}

Jones (2006) defines summarizing strategy as a reading strategy by which the reader takes larger selections of text and reduces them to their bare essentials: the gist, the key ideas, the main points that are worth noting and remembering. Webster's calls a summary the "general idea in brief form"; it's the distillation, condensation, or reduction of a larger work into its primary notions. Readers strip away the extra verbiage and extraneous examples. They focus on the heart of the matter. They try to find the key words and phrases that, when uttered later, still manage to capture the gist of what they have read. They are trying to 
capture the main ideas and the crucial details necessary for supporting them.

Jones (2006) provides for the following procedure of how to teach reading comprehension through the summarizing strategy:

a. After students have used selective underlining on a selection, have them turn the sheet over or close the handout packet and attempt to create a summary paragraph of what they can remember of the key ideas in the piece. They should only look back at their underlining when they reach a point of being stumped. They can go back and forth between writing the summary and checking their underlining several times until they have captured the important ideas in the article in the single paragraph.

b. Have students write successively shorter summaries, constantly refining and reducing their written piece until only the most essential and relevant information remains. They can start off with half a page; then try to get it down to two paragraphs; then one paragraph; then two or three sentences; and ultimately a single sentence.

c. Teach students to go with the newspaper mantra: have they used the key words or phrases to identify only Who, What, When, Where, Why, and How.

d. Take articles from the newspaper, and cut off their headlines. Have students practice writing headlines for (or matching the severed headlines to) the headless stories.

e. Sum It Up: Pat Widdowson of Surry County Schools in North Carolina shared this very cool strategy. How's it work? The teacher has students imagine they are placing a classified ad or sending a telegram, where every word used costs them money. Tell them each word costs 10 cents, and then tell them they can spend so much. For instance, if the teacher says they have $\$ 2.00$ to spend, then that means they have to write a summary that has no more than 20 words. The teacher can adjust the amount they have to spend, and therefore the length of the summary, according to the text they are summarizing. Consider setting this up as a learning station, with articles in a folder that they can practice on whenever they finish their work early or have time when other students are still working.

\section{Review of the Related Studies.}

Pearson (2000) asserts that the strategy allows both students and teachers to monitor comprehension of reading materials. In addition, the strategy helps students understand the organizational structure of the reading text. At last, the strategy is a skill at which most adults must be proficient to be successful.

Jones (2006) states that the strategy facilitates students in improving their reading comprehension because it encourages students to pull out main ideas focus on key details, use key words and phrases, break down the larger ideas, and write only enough to convey the gist.

\section{METHODOLOGY}

This study is categorized as classroom action research. Gay (2000) remarks that action research is intended to describe teacher-initiated, school-based research. It is a process in which individual or several teachers collect the evidence and make decisions about their own knowledge, performance, beliefs, and effects in order to understand and improve them. Hence, this kind of research is aimed at learning and improving their own teaching activities. Reed (2002) asserts that by using an action research, teachers work on problems 
specific to their classrooms and their schools. Snell (1999) explains that an action research is concerned with trying to improving one specific point in a teacher's technique in a particular classroom using empirical measurement. Mettetal (2002) defines classroom action research as systematic inquiry with the goal of informing practice in a particular situation. Thus, it is a way for instructors to discover what works best in their own classroom situation, thus allowing informed decisions about teaching.

\section{Techniques of Data Analysis}

The data will be analyzed qualitatively through inductive analysis. Johnson (2005:83-84) asserts that inductive analysis is used to look up the group of data and try to induce or create order by organizing into group of defining and describing categories such as items, theme, or pattern. Hence, the data resulting from the observations, the test, and the questionnaires will be analyzed inductively by listing themes that have been seen to emerge. In other words, data analysis is concerned with describing what is in the data.

Mills (2003) remarks that interpretation of research findings can be analyzed by adopting the following techniques: unitizing, categorizing, tabulating, and interpreting. Therefore, the techniques of data analysis applied in this research are:

1. Unitizing

Unitizing means to read and to learn all data that have been collected previously. Then, all data units are identified carefully and transferred into index cards.

2. Categorizing

The data are grouped according to their characteristics and types so that each type consists of information that belongs to its class. The data grouping is applied by following scientific criteria.

3. Tabulating

The data that have been grouped according to the criteria in this research are the tabulated data to obtain their frequency of occurrence.

4. Interpreting

Data interpretation is made based on the data that have been grouped according to their classes and types. The data are interpreted by referring to the present theories of teaching-learning strategies that are scientifically recognized by foreign language teaching-learning experts.

\section{DISCUSSION}

Heaton (1989), AbiSamra (2003), and Goodman (2003) assert that reading comprehension is provided by the reader understanding of at least the general and important parts of the reading text. Thus, if the reader has good understanding of the topic, the main idea, and the supporting details of a paragraph, it can be said he/she has reading comprehension class, it is found that the vast majority of the students have satisfactory reading comprehension. In connection with this research of applying the summarizing strategy to reading comprehension class, it is found that vast majority of the students have satisfactory reading comprehension. This is confirmed their average scores that continuously improve during the three cycles - 64.13 through 69.88 to 72.38 (see Table below)

Furthermore, the three questionnaire completions also show that students' perceptions of the application of the summarizing strategy to reading classes get better and better. These can also he seen from the three tables of questionnaire completions that have been presented before.

Pearson (2000), Pages (2003), and Jones (2006) remark that the summarizing 
strategy is the strategy of teaching reading comprehension by which the students are asked to catch the general picture of reading text by grabbing the important points only, for example, the topic, the main idea, and the supporting details. In relation to this research, it is found that the summarizing strategy is proved to be effective as a strategy for teaching reading comprehension. This is also indicated by the improvement of students' reading comprehension during the application of the summarizing strategy in the three cycle (see table below).this finding is confirmed by song (1998), Pearson (2000), Pages (2003), and White (2005), who assert that the summarizing strategy is effective for teaching reading comprehension.

Based on the results of the three reading test, it can be inferred that students' reading comprehension and summarizing ability kept improving during the three cycles. these result are relevant to the views of the proponents of applying summarizing strategy to reading comprehension class.

Table 1 Comparison of Students Average Score During Cycles 1- 3

\begin{tabular}{|c|c|c|}
\hline Cycle & Average Score & Category \\
\hline 1 & 64.13 & Satisfactory \\
\hline 2 & 69.88 & Medium \\
\hline 3 & 72.38 & Good \\
\hline
\end{tabular}




\section{CONCLUSION}

The summarizing strategy proved to be effective for improving students' reading comprehension. This effectiveness is elaborated in the following conclusion:

1. the summarizing strategy is effective for improving students' reading comprehension

2. the summarizing strategy makes students perceive that it is not so difficult to understand an English reading text

3. the summarizing strategy makes students able to determine the main points of a reading text

4. the summarizing strategy improves students' ability write a good summary of a reading text

\section{ACKNOWLEDGEMENTS}

This research of support by PGRI Padang foundation

\section{DAFTARPUSTAKA}

Gay, L.R. and Peter Airasian. (2000). Education Research: Competencies for Analysis and Application. New Jersey: Prentice Hall.

Heaton, John Brian.(1989).Writing English Language tests. New Edition. London: Longman.

Johnson, Andrew P.2005. A Short Guide To Action Research. Boston: Pearson Education Inc.

Jones, Raymond C. "(2006) Strategies for Reading Comprehension:

Summarizing." Reading Quest.: 20 July. http://www.readingquest.org/autho r.html

Mettetal, Gwynn.(2000). Improving Teaching Through Classroom Action Research South Bend: University Of Illinois.
Mills, Geofrey E.(2003).Action Research: A Guide For The Teacher Researcher. New Jersey: Perason Education Inc.

Parsons, Sharon. (1994). Teacher Research. San Jose: San Jose State University.

Pearson, Michael. "Summarizing." Pearson Education. (2000).

http://www.teachervision.fen.co $\underline{\mathrm{m} /}$

Reed, Carol. (2002) "Action Research: A Strategy for Instructional Improvement." New Horizons for Learning.

Snell, Jonathan. "Improving TeacherStudent Interaction In The Efl Classroom: An Action Research Report.'The Internet Tesl Journal.Vol.5.No.4(1999): April. http://iteslj.org/Articles/SnellInteraction.html

Song, Mi-jeong. (1998) "Teaching Reading Strategies in an Ongoing EFL University Reading Classroom." Asian Journal of English Language 